Kuisma Korhonen

\title{
Oulun kirjallisuus - kulttuurista muistia, glokaalia kirjallisuutta, spekulatiivista fiktiota
}

Kirjallisuus oli ensimmäisten oppiaineiden joukossa, kun Oulun yliopistoon perustettiin humanistinen tiedekunta vuonna 1965. Oppiaineen värikästä varhaishistoriaa leimasi marxilaisuus, ensin Raoul Palmgrenin, sitten Pentti Karkaman ja Esko Ervastin johdolla. 1970-luvun lopussa suoraan Cambridgesta Ouluun siirtynyt Kirsti Simonsuuri taas ei tuntenut oloaan laitoksella kotoisaksi, kuten hänen kuuluisasta tilityskirjastaan Pohjoinen yökirja voimme lukea.

Sittemmin oppiaineessa on toiminut monia muitakin vahvoja persoonia kuten Outi Pasanen, Matti Savolainen, Sinikka Carlsson (ent. Tuohimaa), Torsten Pettersson, Liisa Saariluoma (nyk. Steinby), Sanna Karkulehto, Liisi Huhtala sekä edelleen aktiivinen emeritus Kari Sallamaa. Vuodesta 2009 professorina on toiminut Kuisma Korhonen. Hänen lisäkseen vakituista henkilökuntaa ovat tällä hetkellä yliopistonlehtorit Pekka Kuusisto, Jussi Ojajärvi sekä Nina Työlahti. Kirjallisuuden oppiaineen kyljessä on elokuvatutkimus, jota hoitaa yliopistonlehtori Kimmo Laine. Näiden lisäksi oppiaineen ympärille on keräytynyt viime vuosina aktiivinen jatko-opiskelijoiden, tuntiopettajien ja post-docien ryhmä, esimerkiksi viime vuosina väitelleet Marita Hietasaari, Jyrki Korpua ja Hanna-Leena Nissilä.

Kirjallisuuden, elokuvan ja filologia-aineiden kirjallisuusaiheinen tutkimus on järjestäytynyt Literature, history and memory (LHM) -yhteisöksi, joka puolestaan on viime vuonna jakautunut väljästi kolmeen oppiaineen tutkimuksellisia painopisteitä heijastavaan tutkimusryhmään: 1) kirjallinen mielikuvitus ja kulttuurinen muisti, 2) muuttuva yhteiskunta ja glokaalit kirjallisuudet, sekä 3) transkulttuurinen spekulatiivinen fiktio. Uutena avauksena tutkimuksessa on elokuvallisten adaptaatioiden tutkimus - toisin sanoen kirjallisen ja audiovisuaalisen ilmaisun suhde. LHM on myös jäsenyhteisönä Transcultural Encounters -tutkimuskeskuksessa, johon kuuluu lisäksi mm. saamen kulttuurin, suomen kielen, historian sekä aate- ja oppihistorian tutkimusryhmiä.

Pohjoisen kulttuurin tutkimuksella on aina ollut tärkeä sija Oulussa. Oulun yliopiston ihmistieteiden strategisen painopisteen mukaisesti pohjoista lokaalisuutta tarkastellaan yhteydessä globaaleihin kulttuurisiin muutoksiin.

Ihmistieteiden ei pidä jäädä norsunluutorniinsa. Kirjallisuuden oppiaine on omalta osaltaan pitänyt huolta siitä, että kosketuspinta Oulun ja Pohjois-Suomen kulttuurielämään on tiivis ja kahdensuuntainen. Oppiaineen järjestämät yleisöluentosarjat Oulun 
kaupunginkirjastossa mm. Tove Janssonista, Raamatusta ja Kalevalasta ovat vetäneet suuren Pakkala-salin poikkeuksetta täyteen kulttuurinnälkäisiä. Tänä keväänä väkeä on vetänyt yhdessä Turun kotimaisen kirjallisuuden tutkijoiden ja Sanna Karkulehdon kanssa järjestetty Maamme romaani -sarja, jossa käydään läpi suomalaisen romaanitaiteen vuosikymmeniä.

Viimeaikaiset yliopistomaailman myllerrykset eivät ole jättäneet Oulun kirjallisuuttakaan rauhaan. Hallinnollisesti kirjallisuus on tämän vuoden alusta osa kielten ja kirjallisuuden tutkimusyksikköä, jonka johtajana Korhonen toimii.

Hakukohteena vuonna 2017 kirjallisuutta lukemaan pyrkiville on kirjallisuus ja suomen kieli, mutta kirjallisuuden pääaineopiskelijoille varataan sen sisällä 15 aloituspaikkaa. Kirjallisuuden pääaineopiskelijat opiskelevat ensi syksystä lähtien kielten ja kirjallisuuden laaja-alaisessa kandiohjelmassa, missä "laaja-alaisuus" tarkoittaa opiskelijoille lähinnä vapautta valita laajasta valikoimasta sivuainevaihtoehtoja (kuten tähänkin asti), ei niinkään pakollisia yleisopintoja.

Eli selkokielellä: hallintoa ja ministeriöitä varten on rakennettu hallinnollisia himmeleitä, joiden varjossa elämä jatkuu aikalailla kuten ennenkin. On rakenneuudistuksista ollut hyötyäkin: esimerkiksi englantilaisen filologian kirjallisuutta koskeva opetus ja tutkimus on jatkossa entistä tiiviimmin osa kirjallisuuden oppiaineen toimintaa.

Oulun yliopiston tämän kevään Y'T-neuvottelut eivät varsinaisesti koske opetus- ja tutkimushenkilöstöä. Silti ne aiheuttavat huolta, tukipalveluiden karsiminen kun tarkoittaa yleensä töiden siirtymistä yhä harvempien niskalle. Ehkä suurin huolenaihe juuri nyt on kirjaston kohtalo - luonnontieteelliset ja tekniset tiedekunnat haluavat ilmeisesti vyöryttää kirjaston ylläpidon ainoastaan ihmistieteilijöiden huoleksi pöyristyttävillä argumenteilla kuten "eihän nykypäivänä kukaan enää kirjoja tarvitse". Toinen huolenaihe on lähestyvä muutto. Yliopisto on vuokrannut humanistien ja kasvatustieteilijöiden siiven Oulun ammattikorkeakoululle, ja meidän tulisi kesään 2018 mennessä muuttaa uusiin, aiempaa ahtaampiin tiloihin - ja vakuuttaa digiuskovaiset suunnittelijat siitä, että tarvitsemme jatkossakin kirjahyllyjä.

Tulevaisuuden uskoa valaa kuitenkin kirjallisuuden oppiaineen vahva tulos niin tutkintojen kuin julkaisujenkin saralla. Tätä kirjoitettaessa on kaksi väitöskirjaa esitarkastuksessa, eikä väitöskirjojen vuo näytä lähiaikoina tyrehtyvän. Myönteiseksi pitää laskea myös humanistisen tiedekunnan vahva yhteishenki - humanistit vetävät tiiviisti yhtä köyttä, ja poikkitieteellisille projekteille on helppo löytää yhteistyökumppaneita naapurikäytäviltä. Niitä löytyi myös vuonna 2015, kun Kulttuurintutkimuksen päivät pidettiin Oulussa teemalla "Rajat".

Verkottuminen ja yhteistyö niin muiden tieteenalojen kuin maan muiden kirjallisuuden laitosten kanssa tulevat jatkossakin olemaan Oulun kirjallisuuden ohjenuoria. Yhdessä pärjäämme paremmin! 